\title{
A unique cause of interosseous membrane calcification
}

\author{
Ritesh Kumar, Karthik Balachandran, Sadishkumar Kamalanathan, Jaya Prakash Sahoo
}

Department of Endocrinology, Jawaharlal Institute of Post Graduate Medical Education \& Research, Puducherry, India

\section{Correspondence to}

Dr Sadishkumar Kamalanathan, sadishkk@gmail.com

Accepted 8 January 2015

\section{DESCRIPTION}

A 55-year-old man presented with short stature, progressive bilateral leg deformity (figure 1) and loss of all teeth since childhood. Similar bony deformities were present in his mother, elder brother and both his daughters. His only son was, however, asymptomatic. There was no history of fracture. On examination, he had bilateral genu varum with an intercondylar distance of $22 \mathrm{~cm}$. His biochemical evaluation was as follows (reference ranges shown parenthetically): serum calcium $2.35 \mathrm{mmol} / \mathrm{L}$ $(2-2.5 \mathrm{mmol} / \mathrm{L})$, phosphorus $0.77 \mathrm{mmol} / \mathrm{L} \quad(0.81-$ $1.4 \mathrm{mmol} / \mathrm{L})$, alkaline phosphatase $367 \mathrm{mIU} / \mathrm{mL}$ (30-150 $\mathrm{mIU} / \mathrm{mL}), 25(\mathrm{OH})$ vitamin $\mathrm{D} 38 \mathrm{nmol} / \mathrm{L}$ $(75-250 \mathrm{nmol} / \mathrm{L})$, parathormone $11.2 \mathrm{pmol} / \mathrm{L}(0.9-$ $5.5 \mathrm{pmol} / \mathrm{L})$ and creatinine $71 \mu \mathrm{mol} / \mathrm{L} \quad(54-$ $106 \mu \mathrm{mol} / \mathrm{L})$. His tubular maximum phosphate/ glomerular filtration rate was $0.88 \mathrm{mmol} / \mathrm{L}(1.12-1.8)$. $\mathrm{X}$-ray of the forearm showed calcification of the interosseous membrane (figure 2). Dual-energy X-ray absorptiometry scan revealed osteoporosis at his left hip ( $\mathrm{T}$ score of -2.6 ) with paradoxically increased bone density at lumbar spine ( $\mathrm{T}$ score of 2.8). Biochemical evaluation of his mother, elder brother and his daughters showed hypophosphatemia.

The differential diagnosis of interosseous membrane calcification includes fluorosis, ${ }^{1} \mathrm{X}$ linked hypophosphatemic rickets and osteogenesis

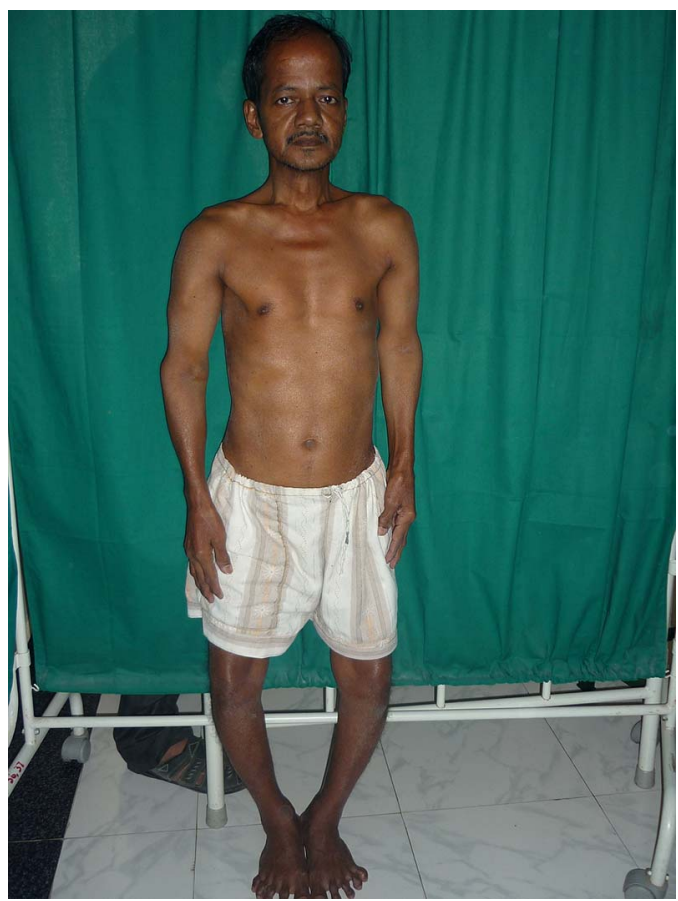

Figure 1 The patient with short stature and bilateral genu varum.

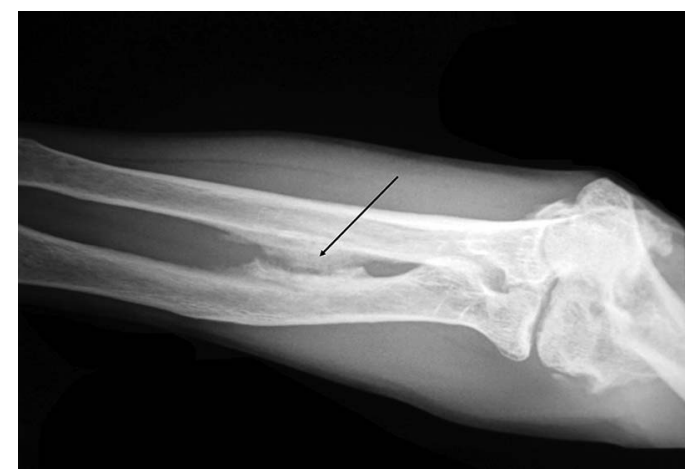

Figure 2 Interosseous membrane calcification in the left forearm.

imperfecta type $\mathrm{V}^{2}$ The presence of three generational family history, bony deformity with dental anomalies, persistent hypophosphatemia and radiological evidence of enthesopathy pointed to a probable diagnosis of $\mathrm{X}$ linked hypophosphatemic rickets. Enthesopathy is a well-documented complication of X linked hypophosphatemic rickets. This explains paradoxical increase in bone density at lumbar spine in our case. Calcification of interosseous membrane is a rare manifestation of enthesopathy in X linked hypophosphatemic rickets. ${ }^{3}$

In less-developed countries, bony and dental deformity with familial or geographic clustering may also occur in fluorosis. The absence of fracture serves to exclude osteogenesis imperfecta as possible cause. The biochemical hypophosphatemia in the patient's family, with characteristic vertical genetic transmission without skipping of generations, absence of father to son transmission and occurrence in all daughters of an affected father, all serve to diagnose the characteristic $\mathrm{X}$ linked dominant inheritance in patient with hypophosphataemic rickets.

\section{Learning points}

- The differential diagnosis of interosseous membrane calcification are: $X$ linked hypophosphataemic rickets, fluorosis and osteogenesis imperfecta type V.

- Presence of hypophosphatemia rules out fluorosis and osteogenesis imperfecta type V.

- Absence of father to son transmission in the family strengthens the diagnosis.

Contributors RK wrote the article and collected the data. KB modified the content and edited the manuscript. SK provided the images and modified the content. JPS made the diagnosis. 
Competing interests None.

Patient consent Obtained.

Provenance and peer review Not commissioned; externally peer reviewed.

\section{REFERENCES}

1 Wang $Y$, Yin $Y$, Gilula $L A$, et al. Endemic fluorosis of the skeleton: radiographic features in 127 patients. Am J Roentgenol 1994;162:93-8.
2 Kim O-H, Jin D-K, Kosaki K, et al. Osteogenesis imperfecta type V: clinical and radiographic manifestations in mutation confirmed patients. Am J Med Genet $A$ 2013;161A:1972-9.

3 Carpenter TO, Imel EA, Holm IA, et al. A clinician's guide to X linked hypophosphatemia. J Bone Miner Res 2011;26:1381-8.

Copyright 2015 BMJ Publishing Group. All rights reserved. For permission to reuse any of this content visit http://group.bmj.com/group/rights-licensing/permissions.

BMJ Case Report Fellows may re-use this article for personal use and teaching without any further permission.

Become a Fellow of BMJ Case Reports today and you can:

- Submit as many cases as you like

- Enjoy fast sympathetic peer review and rapid publication of accepted articles

- Access all the published articles

- Re-use any of the published material for personal use and teaching without further permission

For information on Institutional Fellowships contact consortiasales@bmjgroup.com

Visit casereports.bmj.com for more articles like this and to become a Fellow 